\title{
THE ANALYSIS OF STUDENTS' TEAM ACHIEVEMENT DIVISIONS (STAD) USED IN LEARNING PRACTICE OF TRANSLATING AND INTERPRETING
}

\author{
${ }^{1)}$ Anita Rakhman, ${ }^{2)}$ IsryLailaSyatroh \\ ${ }^{1)}$ Nitzluv@gmail.com
}

Program Studi Pendidikan Bahasa Inggris, STKIP Siliwangi

\begin{abstract}
Due to the Motto of STKIP Siliwangi Bandung “ The Leader of Learning Innovation”, this research deals with The Analysis of Student Teams Achievement Division (STAD) used in Learning Practice of Translating and Interpreting. This research explores the implementation of Students' Team Achievement Divisions (STAD) and find out the advantages and disadvantages of Students' Team Achievement Divisions (STAD) used in learning Practice of Translating and Interpreting. The objective of the research was to motivate students and encourage them to be active in learning, to accelerate student achievement, to improve behavior in learning, and to find out the students' ability with Student Teams-Achievement Divisions (STAD) method. Data collection technique focused on participant observation, interviews, and documentation. Student Team-Achievement Division (STAD) is one type of cooperative learning model using small groups with a number of members of each group of 4-5 students in heterogenic way. It begins by delivering the objectives of learning, delivering of material, group activities, quizzes and group rewards. Students' Team Achievement Divisions (STAD) method also is an effective method of cooperative learning. As with other learning methods, STAD method also has advantages and disadvantages. In the learning process there are good interaction among students, good attitude, increased interpersonal skills. It's effective in increasing student participation and can train students to be more focus, more concentrate in answering questions from the teacher. It can make students eager to learn. But if the chief of the group can not resolve conflicts that arise constructively, it will be less effective in a group work. And if the number of groups is not considered, that is less than four, it would tend to withdraw and less active during the discussion. And if the number of groups of more than five, then chances for them to be passive in task completion
\end{abstract}

Keywords: Student Team Achievement Division (STAD), Cooperative Learning.

\begin{abstract}
ABSTRAK
Karena Motto dari STKIP Siliwangi Bandung "The Leader of Learning Innovation", ini penawaran penelitian dengan Analisis Tim Mahasiswa Berprestasi Divisi (STAD) yang digunakan dalam Pembelajaran Praktek Penerjemahan dan Juru Bahasa. Penelitian ini mengeksplorasi pelaksanaan Mahasiswa Divisi Tim Achievement (STAD) dan mengetahui kelebihan dan kekurangan dari Mahasiswa Divisi Tim Achievement (STAD) yang digunakan dalam pembelajaran Praktek Penerjemahan dan Juru Bahasa. Tujuan dari penelitian ini adalah untuk memotivasi siswa dan mendorong mereka untuk aktif dalam pembelajaran, untuk mempercepat prestasi siswa, untuk meningkatkan perilaku dalam belajar, dan untuk mengetahui kemampuan siswa dengan Divisi Mahasiswa Tim-Prestasi metode (STAD). Teknik pengumpulan data difokuskan pada observasi partisipan, wawancara, dan dokumentasi. Mahasiswa Divisi Tim-Achievement (STAD) merupakan salah satu jenis model pembelajaran kooperatif menggunakan kelompok-kelompok kecil dengan jumlah anggota masing-masing kelompok 4-5 siswa dengan cara yang heterogen. Ini dimulai dengan memberikan tujuan pembelajaran, menyampaikan materi, kegiatan kelompok, kuis dan hadiah kelompok. Divisi Tim Prestasi (STAD) metode siswa juga merupakan metode yang efektif pembelajaran kooperatif. Seperti metode belajar lainnya, metode STAD juga memiliki kelebihan dan kekurangan. Dalam proses pembelajaran ada interaksi yang baik antara siswa, sikap yang baik, peningkatan keterampilan interpersonal. Ini efektif dalam meningkatkan partisipasi siswa dan dapat melatih siswa untuk lebih fokus, berkonsentrasi lebih dalam menjawab pertanyaan dari guru. Hal ini dapat membuat siswa bersemangat untuk belajar. Tetapi jika kepala kelompok tidak dapat menyelesaikan konflik yang muncul secara konstruktif, akan kurang efektif dalam kerja kelompok. Dan jika jumlah
\end{abstract}


kelompok tidak dianggap, yang kurang dari empat, itu akan cenderung menarik diri dan kurang aktif selama diskusi. Dan jika jumlah kelompok lebih dari lima, maka kemungkinan bagi mereka untuk menjadi pasif dalam penyelesaian tugas.

Kata Kunci: Tim Mahasiswa Prestasi Divisi (STAD), Cooperative Learning.

\section{A. INTRODUCTION}

Learning English is fun. If you want to master English then you should like learning English. English teaching is carried out in many parts of the world. Indonesia, for example, treats English teaching successful, we have to consider some factors such as quality of the teacher, school buildings, library, and books. The teacher should combine it as a formula to teach. Teachers should know how to teach English well and how to make students fun by learning English. As the experience of the researcher, sometimes many students attend their class only want to sign the attendance list with no participation at all. They sit with no sound. Then the researcher found the way how to make the learning activity alive. How to alive the class, even somehow it's not always perfect. There are many ways to teach English. Teacher should know the best way to teach English in order the entire student satisfied with it.

In accordance with the vision of STKIP "The Leader of Learning Innovation" so, the researcher want to share a research about Learning Innovation. It's about cooperative learning. According to Slavin (in Dat Tran, 2013), Cooperative learning comprises "instructional methods in which teachers organize students into small groups, which then work together to help one another learn academic content". Cooperative learning is defined by a set of processes which help people interact together in order to accomplish a specific goal or develop an end product which is usually in a specific content. In the cooperative learning the teacher maintains complete control of the class, even though the students work in groups to accomplish a goal of a course. There are various types of cooperative learning; one of them is Student Teams-Achievement Divisions (STAD). According to Slavin (in Van Wyk, 2010) "the main idea behind STAD is to motivate students to encourage and help each other master skills presented by the teacher". In Student TeamsAchievement Divisions (STAD), students are assigned to four or five member learning groups. The groups are set of high, average, and low performing students, and of boys and girls of different racial or ethnic backgrounds. Thus, each group is a microcosm of the entire class. In a glance about using Student Teams-Achievement Divisions (STAD) method, the teacher first introduces new materials to be learned. The team members then study worksheets on the material until they master the material. Individual quizzes are taken on the material studied. The teacher then combines the scores to create team scores. Members of the winning team are given the highest scores for the final scores accepted.

Translation has its own excitement, its own interest. A satisfactory translation is always possible, but a good translator is never satisfied with it. It can usually be improved. Translating is rendering the meaning of a text into another language in the way that the author intended the text (Newmark, 1988: 5). While interpreting refers to the process of changing massage produced in one language immediately into another language (Gentile, 1996). In learning practice of translating and interpreting, the teacher teach in a short case the definition about translating and interpreting and its differences then practice it. In order to get maximum participation from all the student about the subject, so the researcher try to take Student Teams-Achievement Divisions (STAD) method. By practicing translating and interpreting used Student Teams-Achievement Divisions (STAD) method, the researcher hope all the student can enjoy the subject, and they excite it. The class becomes alive. So, the writer will take the title "The Analysis of Student Teams-Achievement Divisions (STAD) in Learning Practice of Translating and Interpreting“.

\section{B. LITERATURE REVIEW AND METHODOLOGY}

\section{Literature Review}

\section{a. Cooperative Learning}

\section{1) Definition of Cooperative Learning.}

Cooperative learning is a broader concept covering all types of group work including more forms led by the teacher or directed by the teacher. Cooperative learning is generally considered to be 
more directed by the teacher, where the teacher assigns tasks and questions and provide materials and information designed to help learners to solve the problem in question. Teachers usually set up the particular exam at the end of the task. (Suprijono, 2013:54). In other words, we can say that cooperative learning provides students with an opportunity to practice skills or learn content presented by the teacher, emphasizes team goals, and team success only if each individual learns and conducive for creating successful inclusive experiences with students with disabilities.

According to the Johnson \& Johnson model (in Felder and Brent, 2007):, cooperative learning is instruction that involves students working in teams to accomplish a common goal, under conditions that include the following elements:

a) Positive interdependence. Team members are obliged to rely on one another to achieve the goal. If any team members fail to do their part, everyone suffers consequences.

b) Individual accountability. All students in a group are held accountable for doing their share of the work and for mastery of all of the material to be learned.

c) Face-to-face proactive interaction. Although some of the group work may be parceled out and done individually, some must be done interactively, with group members providing one another with feedback, challenging reasoning and conclusions, and perhaps most importantly, teaching and encouraging one another.

d) Appropriate use of collaborative skills. Students are encouraged and helped to develop and practice trust-building, leadership, decision-making, communication, and conflict management skills.

e) Group processing. Team members set group goals, periodically assess what they are doing well as a team, and identify changes they will make to function more effectively in the future.

Cooperative learning is not simply a synonym for students working in groups. A learning exercise only qualifies as cooperative learning to the extent that the five listed elements are present.

\section{2) Cooperative Learning Models}

There are several terms to refer to social-based learning; there are cooperative learning and collaborative learning. Panitz distinguish it into two. Collaborative learning is defined as a philosophy of personal responsibility and attitude of respect for others. Learners are responsible for their own learning and trying to find information to answer the questions which given by the teacher. The teacher acts as a facilitator, providing support but do not steer the group towards the results that had been prepared beforehand. The forms of assessment by fellow students used to see the results of the process. Cooperative learning is a broader concept that includes all kinds of group work including more forms led by a teacher or directed by the teacher. Generally considered to be more cooperative learning directed by the teacher, which teachers assign tasks and questions as well as provide materials and information designed to help students solve the problem in question. Teachers usually assign a specific test form at the end of the task (Suprijono, 2013:54).

\section{a) The Implementation of Cooperative Learning}

There are six main steps or stages in using cooperative learning (Ibrahim at all in Trianto, 2007:48). The measures shown in Table 2.1.

Table 2.1. The Implementation of Cooperative Learning.

\begin{tabular}{|c|c|}
\hline Phase & Teachers' Behavior \\
\hline Phase 1 & Teachers convey all the \\
\hline $\begin{array}{l}\text { Outlines the objectives } \\
\text { and motivate students }\end{array}$ & $\begin{array}{l}\text { objectives of learning in } \\
\text { the subjects and motivate } \\
\text { students in learning. }\end{array}$ \\
\hline Phase 2 & The teacher presents \\
\hline Delivering & information to students \\
\hline Information & $\begin{array}{l}\text { with demonstrations or } \\
\text { through the reading } \\
\text { material. }\end{array}$ \\
\hline Phase 3 & The teacher explains to \\
\hline $\begin{array}{l}\text { Organize students into } \\
\text { cooperative groups }\end{array}$ & $\begin{array}{l}\text { students how to form } \\
\text { study groups and help } \\
\text { each group in order to } \\
\text { make the transition } \\
\text { efficiently. }\end{array}$ \\
\hline Phase 4 & Teachers guide study \\
\hline $\begin{array}{l}\text { Guiding Team work } \\
\text { and learn }\end{array}$ & $\begin{array}{l}\text { groups when they do their } \\
\text { work. }\end{array}$ \\
\hline Phase 5 & Teachers evaluate \\
\hline evaluation & $\begin{array}{l}\text { learning outcomes about } \\
\text { the material lesson who } \\
\text { have studied or each } \\
\text { group presented their } \\
\text { work. }\end{array}$ \\
\hline
\end{tabular}


Phase 6

reward
Teachers looking for the better ways to appreciate the effort and the learning outcomes of individuals and groups.

\section{b. Students' Team Achievement Divisions (STAD).}

1) Definition of Students' Team Achievement Divisions (STAD).

Cooperative learning Students' Team Achievement Divisions (STAD) is one type of cooperative learning model using small groups with a number of members of each group of 4-5 students heterogenic. In conveying the lesson begins with the objectives of learning, delivery of material, group activities, quizzes and group awards. Slavin (in Nur 2000:26, in Trianto (2007: 52) states that, the Students' Team Achievement Divisions (STAD) students are placed with learning teams of 4-5 people who are a mixture according to the level of achievement, gender and ethnicity. The teacher presents a lesson, and then the students work on their team to make sure that all team members have mastered the lesson. Then, all students are given a test on the material; at the time of this test they should not help each other.

2) Preparations of implementation the Students' Team Achievement Divisions (STAD).

As with the other learning, Students' Team Achievement Divisions (STAD) also requires preparation before learning activities is implemented (Trianto, 2007:52). Preparations include:

a) Learning device. Prior to conducting this study need to be prepared learning device, this includes lesson plans, student books, and student activity sheet along with the answer sheet.

b) Forming cooperative groups. Determining the group members with the ability of students in a group which are heterogenic and the ability between one group to another relatively homogeneous.

c) Determining the initial score. Initial score that can be used in a cooperative classroom is the previous test scores. The initial score may change after the quiz.

d) Seating arrangements. The seating arrangements in the cooperative classroom should also be regulated; this is conducted to support the successful of cooperative learning. If there is no seating arrangement can lead to chaos that led to the failure of cooperative learning in the classroom.

e) Teamwork. To prevent barriers to cooperative learning Students' Team Achievement Divisions (STAD), first held practice teamwork. It aims to introduce each individual in the group.

3) Five Main Steps of Implementation Students' Team Achievement Divisions (STAD).

According to Suprijono (2013:133), there are some steps in implementing Students' Team Achievement Divisions (STAD) as follows:

a) Form groups of 4-5 students in heterogeneous members (mix according to achievement, gender, ethnicity, etc.).

b) Teachers present the lessons.

c) Teacher gives a task to the group and it will be answered by members of the group. Members who already understand can explain to other members until all members understand.

d) Teacher gives a quiz or question to all students. When answering the quiz should not help each other out.

e) Giving the evaluation

f) Conclusions.

\section{4) Learning Translating and Interpreting}

In the field of translation theory the terms of translation and interpretation are used in different contexts even though the term was focused to transfer the messages from the source language to the target language (Nababan, 2008:18). Translation has been defined in various ways with the theoretical background and a different approach. Catford (in Machali, 2009: 25) uses the language in view of the translation and he defines it as "the replacement of textual material in one language (SL) by equivalent textual material in another language (TL)". Newmark (1988) also gives a similar definition, but more clearly "rendering the meaning of a text into another language in the way that the author intended the text". Further disaggregation can be concluded that the translation is an attempt to replace the source language text with the text equivalent in the target language. A translation is something that has to be discussed. Translation is for discussion.

Interpreting refers to the process of changing massage produced in one language immediately 
into another language (Gentile, 1996). Why Interpreting is needed? First is the diversity of language. Every country around the world or even in one country has more then one language used by the citizen this condition made the people need a method to communicate between speakers from different languages and from this case interpreting appears. Second is multilingual condition. This multilingual condition not always require an interpreting, in this situation, communication problem maybe overcome by use a Lingua Franca. And lingua Franca generally not uses a mother tongue. Third is a geographical boundary. This condition leads people to have a little understanding of the language of others who lived even a little distance away. This condition may lead to the social antagonism and event conflict. This condition can be resolved by a having a lingua franca or by using an interpreter. Fourth is citizen or people awareness. In this condition certain social groups gain multilingual skill, their try to understand more then one language.

\section{Methodology}

\section{a. Research Method}

In conducting the research, an appropriate methodology plays an important role because it deals with a system of ways of doing or studying something. The method of this research is qualitative research. It is based on the research focus to analyze the implementing of Student Teams-Achievement Divisions (STAD) method in practice of translating and Interpreting on class A2 2011 English Education STKIP Siliwangi Bandung. Bodgan and Biklen (in Sugiyono, 2010:9) state that qualitative research has some characteristics as follows:

1) Qualitative research has the natural setting as the direct source of data and researcher is the key instrument.

2) Qualitative research is descriptive. The data collected is in the form of words of pictures rather than number.

3) Qualitative research is concerned with process rather than simply with outcomes or products.

4) Qualitative research tends to analyze their data inductively.

5) "Meaning" is essential to the qualitative research. b. Instrument of the Research

In this research, the researcher itself as an instrument or as a tool of the research. By the researcher as an instrument which must be valid of how far the qualitative researcher is ready to conduct further research into the field. In terms of qualitative research instruments, Lincoln and Gaba (in Sugiyono 2010: 223) states that:

"The instrument of choice in naturalistic inquiry is the human. We shall see that other forms of instrumentation maybe used in later phases of the inquiry, but the human is the initial and continuing mainstay. But if the human instrument has been used extensively in earlier stages of inquiry, so that an instrument can be constructed that is grounded in the data that the human instrument has product".

\section{c. Time and Place}

The researcher conducted the research on Class A2 2011 English Department on STKIP Siliwangi, Bandung. This research was conducted from 7 th until 28th of June 2014.

\section{d. Data Collection Technique}

In this research, in qualitative research the data obtained from various sources, using data collection techniques (triangulation), and carried out continuously until data are collected. In qualitative research, data collection is conducted with natural setting, the primary data source, and data collection techniques more on participant observation, in dept interviews, and documentation (Sugiyono, 2010:225).

1) Observation

Marshall (1995, in Sugiyono 2010: 226) stated that through observation, the researcher learns about behavior and the meaning attached to those behaviors. Observations enable the researcher to gather data on the physical setting, human setting, interactional setting, and program setting. By doing observation, the researcher can see and know the students' ability in practicing translating and interpreting used Student Teams-Achievement Divisions (STAD) method.

2) Interview

Esternberg (in Sugiyono, 2010:231) stated that an interview is a meeting of two persons to exchange information and idea through question and responses, resulting in 
communication and joint construction of meaning about a particular topic. In this research, researcher will do the interview with the three representative students of clas A2 2011 to ask more about Student TeamsAchievement Divisions (STAD) method used in Practice of Translating and Interpreting.

3) Documentation

Documentation is the past event note. Document may take the form of text, images, or the monumental works of a person (Sugiyono, 2010:240). By this method, researcher seeks the data about implementing of Student Teams-Achievement Divisions (STAD) method used in translating and interpreting of class A2 2011 English department students of STKIP Bandung.

\section{e. Data Analysis Technique}

In qualitative research, the data obtained from various sources, using data collection techniques and continuously conducted until data are collected (Sugiyono, 2010:243). Data analysis can be defined as the process of bringing the order, structure, and interpretation to the mass of collected data. In this research, researcher will use qualitative data analysis. We get the qualitative information from data such as journals, interviews, and observation notes. There are some processes in data analysis; such as making notes in the process of implementing Student Teams-Achievement Divisions (STAD) method in the classroom. Data analysis on the field was done when collecting data and after collecting the data. The activities on the qualitative data were done interactively and continue until complete. There are three activities on data analysis; data reduction, data display, and conclusion drawing/ verification.

\section{1) Reduction of the Data}

Data obtained is quite a lot from the field, for it should be noted carefully and more detail. In reducing the data, the researcher will be guided by the objectives to be achieved. The main goal of qualitative research is the finding. Reduction refers to resume the data, choosing main things, focusing on the important things, look for the theme. Therefore, data that was reduced will give clearer drawing and make the researcher easier to collect the next data. Next steps from these activities are focusing, and make simpler the data, and transforming raw data that were written on the field note. Reduction steps in this research are: a) Resume the result of documentation

b) Classify the result of documentation and interview the students.

c) The result of interview and documentation will be transforming into the note.

\section{2) Display the Data}

After reduction the data, next step is display the data. Display the data is the collection of information which arranged and gives possibility to get the conclusion and take the action. By displaying the data, the data will be organized, arranged. Therefore, it will make easier to be understood. On the qualitative research, displaying data can be done on the short description, draft, flowchart, etc. Some activities of display the data on this research are:

a) Display the documentation and interview data that was done and has been arranged into written text.

b) Display the data from the observation about Student Teams-Achievement Divisions (STAD) method analysis and its advantages and disadvantages.

\section{3) Conclusion Drawing/Verification.}

The third step in the analysis of qualitative data according to Miles and Huberman is the conclusion and verification. Verification refers to the process which is able to answer research questions and research objectives. Beginning conclusion is still temporary, and will be changed if there isn't strong data that support on the next step in collecting data. But, if the beginning conclusion is supported by valid data and consistent, when the researcher backs to the field, so the conclusion is credible.

On this research, withdrawing the conclusion is doing by comparing between observation data, documentation data, and interview data. The researcher will get conclusion about the analysis of Students' Team Achievement Divisions (STAD) used in learning Practice of Translating and Interpreting.

\section{FINDINGS AND DISCUSSION}

\section{Findings}

Researchers conducted a field study to find information and data that has been prepared in advance. In obtaining the information, the 
researchers ask questions through observation and interviews. Here is a description of the observation and interviews with the representative of students of the class A2, 2011. Data of implementation of Students' Team Achievement Divisions (STAD) used in learning Practice of Translating and Interpreting activities are described as follows:

\section{a. First meeting, May 7th, 2014.}

First activity, at the first meeting of the learning activity, the researchers focused on the introduction of Student Teams-Achievement Divisions (STAD) method and the purpose of Student Teams-Achievement Divisions (STAD) method in learning Practice of Translating and Interpreting to the students of class A2 2011. This section will be built in 90 minutes. As with other learning, the researcher has preparation before learning activities undertaken. Before going to the class, the researcher prepares her lesson plans and student activity sheet along with the answer sheet.

Second activity, the researchers go to class, it starts with greeting then prayed together. Then as usual researchers asked the day and date to the students and then ask the student about the last material. The researcher review the last material at the last meeting and starts to introduce Student TeamsAchievement Divisions (STAD) method and the purpose of Student Teams-Achievement Divisions (STAD) method in learning practice of Translating and Interpreting. After talking about Student Teams-Achievement Divisions (STAD) method then the researcher start to form the cooperative groups. The researcher classified the members which appropriate to their achievements. In every each groups they have the members who have well in score. In this first meeting, the researcher already has the score of the students on the previous quiz in the last meeting. The initial score may change after the quiz. So, the researcher just mixes the group members to make the learning alive. There are ten groups which divided into each group 5 students. After forming groups, researcher arranges the seats to support the success of implementing cooperative learning. To prevent barriers in Students' Team Achievement Divisions (STAD), the researcher held practice teamwork. It aims to introduce each individual in the group. Then they can learn as a team and can help in understanding the materials each other. The researcher read the attendance list. Before entering the core activity, researchers conveyed the learning objectives and the researcher have conversations with students.

Third activity, the researcher begins to present the lesson. It begins with the material about methods of translation. There are eight methods of translation. The researcher starts to explain in front of the class about the methods of translation one by one. The researcher only explains four of eight methods of translation because of the time constraint. Members who already understand can explain to other members until all members understand.. The researcher gives a task to the groups which have to be answered by the members of the group. The researcher's walking around the class to see communication and participation in every each groups. In order when they're answering the quiz they should not help each other out. The researcher collected the entire quiz and then returns it back by way of exchange answer sheet of students.

Fourth activity, the researcher corrected the answers. The first step that must be done in this activity is to calculate the value of the group and the value of the development of individual and group achievement reward. The awarding of the group based on the average value of the development of individuals in the group. The researcher gave the stars to the winning team. The researcher provided an evaluation of the material and the results of the students' answers.

Fifth activity, this is the last activity learning on the first meeting is conclusion. The researcher reviews four methods of translation and for the four methods more will be continued at next meeting. The last is the researcher say greeting to the students.

\section{b. Second Meeting, May 14th, 2014.}

First activity, at the second meeting of the learning activity, the researcher just about to continue on the last material it's about the methods of translation by using Student Teams-Achievement Divisions (STAD) method in learning practice of Translating and Interpreting to the students of class A2 2011. This section will be held in 90 minutes. The researcher has preparation before learning activities undertaken. The researcher prepare her lesson plans, student activity sheet along with the answer sheet. 
Second activity, the researcher came into the class, it starts with greeting then prayed together. The researcher read the attendance list. Then the researcher starts to order the students to seat accordant to the last meeting. It appropriated with the achievements they had from the last meeting. There are ten groups which divided into each group 5 students. They can learn as a team and can help in understanding the materials each other. Before entering the core activity, researchers conveyed the learning objectives and the researcher have conversations with students.

Third activity, the researcher begins to present the lesson. She continued the material about methods of translation. There are still more four methods of translation which didn't explain yet. The researcher starts to explain in front of the class about the methods of translation one by one. Members who already understand can explain to other members until all members understand.. The researcher gives a task to the groups which have to be answered by the members of the group. The researcher's walking around the class to see the communication and participation in every each groups, in order when they're answering the quiz they should not help each other out. The researcher collected the entire quiz and then returns it back by way of exchange students answer sheet.

Fourth activity, the researcher corrected the answers. The first step that must be done in this activity is to calculate the value of the group and the value of the development of individual and group achievement reward. The awarding of the group based on the average value of the development of individuals in the group. The researcher gave the stars to the winning team. The researcher provided an evaluation of the material and the results of the students' answers.

Fifth activity, the last activity learning on the second meeting is conclusion. The researcher reviews the last four methods of translation and reviews all the methods of translation. The last is the researcher say greeting to the students.

\section{c. Third meeting, May 21st, 2014.}

First activity, at the third meeting of the learning activity, the researcher starts to begin the new material. This section will be held in 90 minutes. The researcher prepare her lesson plans, student activity sheet along with the answer sheet.
Second activity, the researcher came into the class, it starts with greeting then prayed together. The researcher read the attendance list. Then the researcher starts to order the students to seat accordant to the last meeting. There are ten groups which divided into each group 5 students. They can learn as a team and can help in understanding the materials each other. Before entering the core activity, researchers conveyed the learning objectives and the researcher have conversations with students.

Third activity, the researcher begins to present the lesson. The researcher begins to explain about the modes of interpreting. The researcher starts to explain in front of the class about the methods of translation one by one. Members who already understand can explain to other members until all members understand.. The researcher gives a task to the groups which have to be answered by the members of the group. The researcher's walking around the class to see the communication and participation in every each groups, in order when they're answering the quiz they should not help each other out. The researcher collected the entire quiz and then returns it back by way of exchange students answer sheet.

Fourth activity, the researcher corrected the answers. The first step that must be done in this activity is to calculate the value of the group and the value of the development of individual and group achievement reward. The awarding of the group based on the average value of the development of individuals in the group. The researcher gave the stars to the winning team. The researcher provided an evaluation of the material and the results of the students' answers.

Fifth activity, the last activity learning on the third meeting is conclusion. The researcher reviews the modes of interpreting. The last is the researcher say greeting to the students.

\section{d. Fourth meeting, May 28th, 2014.}

First activity, at the fourth meeting of the learning activity, the researcher explained about the comparison between translation and interpretation. This section will be held in 90 minutes. The researcher prepare her lesson plans, student activity sheet along with the answer sheet.

Second activity, the researchers go to class, it starts with greeting then prayed together. Then as usual 
researchers asked the day and date to the students and then ask the last material. The researcher read the attendance list. Then the researcher starts to order the students to seat accordant to the last meeting. There are ten groups which divided into each group 5 students. They can learn as a team and can help in understanding the materials each other. Before entering the core activity, the researcher conveyed the learning objectives and the researcher have conversations with students.

Third activity, the researcher begins to present the lesson. She compared the differences between translating and interpreting. The researcher starts to explain in front of the class about compared the differences between translating and interpreting. Members who already understand can explain to other members until all members understand.. The researcher gives a task to the groups which have to be answered by the members of the group. The researcher's walking around the class to see the communication and participation in every each groups, in order when they're answering the quiz they should not help each other out. The researcher collected the entire quiz and then returns it back by way of exchange students answer sheet.

Fourth activity, the researcher corrected the answers. The first step that must be done in this activity is to calculate the value of the group and the value of the development of individual and group achievement reward. The awarding of the group based on the average value of the development of individuals in the group. The researcher gave the stars to the winning team. The researcher provided an evaluation of the material and the results of the students' answers.

Fifth activity, the last activity learning on the fourth meeting is conclusion. The researcher reviews the differences between translating and interpreting. The last is the researcher say greeting to the students.

Here is a description of the results of interviews with three students who can be described as follows:

\section{1) Student 1}

The first responder called Kholidah Rizkiah, she was born on April 4th, 1993. She lives in Cikampek, Karawang. She is a chief of class a2 2011. According to the results of interviews conducted by researchers, can be presented as follows:

As a type of cooperative learning by using STAD method in the learning process, it's quite effective in increasing student participation and can train students to be more focus, more concentrate in answering questions from the teacher. And of course this is different from another, it's fun. Students feel more exciting in learning process.

The weakness of STAD method as one of a type in cooperative learning is when the method is carried out not all of the students participates into it. There is no active and passive. While this method is so exciting but, there are still some of them try to be cool in learning (no participate). The advantage is that students are trained to be responsive in answering questions of teachers. And it can crease their ability of using English in the classroom.

\section{2) Student 2}

The second responder called Aiga Ulfa Saputri, she was born on May 24 1993. She lives in Sarijadi street block 13 Bandung. She is a student of class a2 2011. According to the results of interviews conducted by researchers, can be presented as follows:

To follow the lesson it's not difficult, because it is easy to understand and can be understood. It's different from the ordinary teaching methods, STAD method can lead the students to feel more fun because the students can cooperate with other friends in a group as teamwork to ask something that is not understand yet, without any shame to ask. The learning activity felt so different, more active and the students feel fun.

The disadvantages of STAD method may be one of the members of the group who did not say anything because they feel less confident. The advantages of learning STAD method is so easy to understand.

\section{3) Student 3}

The third responder called Dea Anugerah Suci; she was born on April 3rd 1994. She lives in Tirtajaya Karawang. She is a student of class a2 2011. According to the results of interviews conducted by researchers, can be presented as follows: 
STAD method in cooperative learning makes students eager to learn. So that students are motivated to show themselves and this type make students feel fun to learn.

Disadvantages of STAD method or its weakness is the position seat of a group; it's affected to the activity of a group. The seat position of the group where behind, can lead to the less noticed from the teacher. The advantage of STAD method is students more active to answer the questions of the teacher in order to get points

\section{Discussions}

The implementation of Students' Team Achievement Divisions (STAD) method with the advantages and disadvantages of Students' Team Achievement Divisions (STAD) used in learning Practice of Translating and Interpreting

Students' Teams Achievement Division (STAD) is one method in a simple cooperative learning, it is for teachers who are just beginning to use cooperative approach in the classroom. STAD method also is an effective method of cooperative learning. Student Team-Achievement Division (STAD) is one type of cooperative learning model using small groups with a number of members of each group of 4-5 students in heterogenic way. It begin by delivering the objectives of learning, delivering of material, group activities, quizzes and group rewards (Trianto, 2007:52).

Students work together in achieving its objectives by upholding the norms of the group. Motivate students to increase their passion of learning. It's important to form study groups so that each student has a sense of responsibility and a feeling of positive interdependence because each member has a role as well in achieving the group's success. Model of cooperative learning is an approach or a series of strategies specifically designed to give a boost to the learners to cooperate during the learning process. STAD method also adds an extra source of learning within the groups because some high achievers act as a role of teacher, which result in high achievements. It enables the students according to the requirements of the modern society to work with their colleagues competently and successfully.

The STAD method is most appropriate for teaching well-defined objectives with single right answers. However, it can easily be adapted to use with less well-defined objectives by incorporating more open-ended assessments, such as essays or performances. The situation in the classroom needs to be planned and constructed in such a way that students get the opportunity to interact with each other. This interaction will form a community that allows them to understand the process of learning and understanding each other. Things to remember in implementing STAD method as follows:

1) Students work toward mastery of material.

2) Can use whatever method works best will in teams.

3) Cannot help one another out during quizzes.

4) Score is based on previous score; higher individual score is higher team score.

5) Must test every week for it to work, look for improvements.

6) Keep accurate records of scores, improvements, same, or less than week before.

7) Recognize team scores in form of a newsletter.

In carrying out the study, the researcher felt at the end of the study that by using STAD method it showed there are some advantages and disadvantages in STAD method. By using Student Teams-Achievement Divisions (STAD) method encourage them to argue. In the laerning process by using Student Teams-Achievement Divisions (STAD) method, there are good interaction among students, improve positive attitude, good attitude, increased interpersonal skills. It's effective in increasing student participation and can train students to be more focus, more concentrate in answering questions from the teacher.

STAD method can lead the students more fun in learning process because the students can cooperate with other friends in a group as teamwork to ask something that is not understand yet, without any shame to ask. STAD method in cooperative learning makes students eager to learn. Students like to contribute mean that he is work harder, see improvements, and see learning as social instead of isolated. Students begin help one another out. Great for academics, making connections to others.

The advantages and disadvantages of STAD Methods. According to Slavin in Hartati (1997: 21) cooperative learning has advantages and disadvantages as follows: 
Advantages:

1) Can develop student achievement, both in results of teacher-made test as well as a standard test.

2) Students' self-confidence increased, students feel more controlled for academic success.

3) Cooperative strategy provides an impressive development in interpersonal relationships between members of different ethnic groups.

Disadvantages:

1) If teachers are not reminding students to always use the skills cooperative in the dynamics of the group, it will stuck.

2) If the number of groups is not considered, that is less than four, for example three, then a member would tend to withdraw and less active during the discussion and if the number of groups more than five, then chances for them to be passive in task completion.

3 ) If the chief of the group can not resolve conflicts that arise constructively, it will be less effective for group work.

\section{CONCLUSION}

Students' Teams Achievement Division (STAD) is one of a simple method in cooperative learning for teachers who are just beginning to use cooperative approach in the classroom. Student TeamsAchievement Divisions (STAD) method also is an effective method of cooperative learning. Student Team-Achievement Division (STAD) is one type of cooperative learning model using small groups with a number of members of each group of 4-5 students in heterogenic way. It begins by delivering the objectives of learning, delivering of material, group activities, quizzes and group rewards.

As with other learning methods, Student TeamsAchievement Divisions (STAD) method also has advantages and disadvantages. There are good interactions among students, improve positive attitude towards subject, good attitude, increased interpersonal skills. Student Teams-Achievement Divisions (STAD) method can lead the students more fun in learning process because the students can cooperate with other friends in a group as teamwork to ask something that is not understand yet, without any shame to ask. Student TeamsAchievement Divisions (STAD) method in cooperative learning makes students eager to learn. But if the chief of the group can not resolve conflicts that arise constructively, it will be less effective in group work. And if the number of groups is not considered, that is less than four, it would tend to withdraw and less active during the discussion.

1) Student Team Achievement Division (STAD) learning method can be an alternative learning model. However, the suitability of the material should be viewed with a learning model that will be used. The use of alternative models of teaching and learning need to be added to the students, so that students can more easily understand the material.

2) Through cooperative learning, teachers are expected to be able to more effectively manage the classroom.

3) Active role teacher as a peer to further enhance the success of the group.

4) The implementation of STAD method, preferably in one member of the group assigned to read different sections, so that they can gather and exchange information.

5) Teachers can evaluate on all parts of the material. In this way, each member feels responsible to complete the task well.

\section{E. BIBLIOGRAPHY}

Gentile, Adolfo. 1996. Liaison Interpreting. A Handbook. Australia. Melbourne University Press.

Hartati, Sri. 1997. Strategi pembelajaran kooperatif dalam proses belajar mengajar biologi di SMA. Jakarta: Edukasi.

Nababan, M, Rudolf. 2008. Teori Menerjemah

Bahasa Inggris. Yogyakarta. Pustaka Pelajar.

Newmark, Peter. 1988. A Textbook of Translation. UK. Prentice Hall International Ltd.

Sugiyono. 2013. Metode Penelitian Kuantitatif, Kualitatif, Dan R\&D. Bandung. Alfabeta.

Suprijono, Agus. 2013. Cooperative Learning. Teori dan Aplikasi Paikem. Yogyakarta. Pustaka Pelajar.

Trianto. 2007. Model-model Pembelajaran Inovatif Berorientasi Konstruktivistik. Konsep, Landasan Teoritis-Praktis dan Implementasinya. Jakarta. Prestasi Pustaka.

Van Wyk, Micheal. 2010. Do Student Teams Achievement Divisions Enhance Economic Literacy? An Quasi-experimental Design. South Africa. Department of Curriculum Studies, Faculty of Education, University of the Free State. 
Tran, Van Dat. 2013. Effects of Student Teams Achievement Division (STAD) on Academic Achievement, and Attitudes of Grade 9th Secondary School Students towards Mathematics. Australia. Faculty of Education, La Trobe University. 